\title{
Character-Based History Worksheet for Grade X Students
}

\author{
Yan Driya Samodra*; Dyah Kumalasari \\ State University of Yogyakarta, Indonesia \\ Email: yansamodra@gmail.com
}

http://dx.doi.org/10.18415/ijmmu.v5i1.129

\begin{abstract}
This research aimed at finding out: (1) the development of character-based History worksheet, (2) the appropriateness of character-based History worksheet for grade $X$ students, and (3) the implementation of character in History worksheet. This research fitted Research and Development adapting development model from Borg \& Gall (1983). Seven steps were adapted: (a) collecting information, (b) planning, (c) developing preliminary form of product, (d) conducting preliminary field testing, (e) revising main product, (f) conducting main field testing, and (g) revising operational product. The data were collected through survey, observation, and interview. The result of this research was a set of character-based worksheet. It embodied six units. To find out the feasibility, the worksheets were validated by experts and field tested. The result showed that the product had been appropriate to be used as it met the students' needs and the employed curriculum.
\end{abstract}

Keywords: Worksheet; Character education; History teaching; 2013 curriculum

\section{Introduction}

National education in Indonesia is an education in which the lifeline of the citizen (cultureelnationaal) becomes the basis. It aims at improving the degree of the country and its citizen to be able to cooperate with other nation for the global prosperity (Dewantara, 2013, p.15). Regarding the development of national education system, the Indonesian government had set the vision, mission, and strategy of national educational development. The vision of which is as a potential educational system to develop critical and active Indonesian citizen to face the globalization (Rusman, 2011, p.3). In regard to this vision, the government encourages the teachers in Indonesia, particularly History teachers, to be able to develop a set of learning materials which can help the students to be critical and creative.

However, there are insufficient learning materials in the classroom to achieve the aim. The materials for History class was broad. The books provided by the government do not help the students to build their creativity and critical thinking. The worksheet used was monotonous. In fact, most of the schools in Indonesia setting still used the traditional worksheet. A publisher had designed it, and the teacher did not make any changing to plan, prepare, or design own worksheet (Prastowo, 2012, p.18). The teacher was aware that most of the worksheet presented commercially did not meet the core competence and basic competence proposed. Thus, it limits the students' characteristics and competencies. 
Moreover, the Indonesian government emphasizes more on implementing character education program to achieve the aim. In this program, education becomes a way to form traits such attitude, honesty, responsibility, in which the result can be seen directly (Lickona, 1991, p.290). In line with him, Berkowitz (2011, p.414) defines character education as a conscious development occurred at school as the tendency and capacity of young learners to be a good, responsible, pro-social, obedient, and democratic citizen. It becomes a concept of education which plays a great role in students' moral development (Marlyn, 2014, p.159).

In Indonesia, the values in character education are derived from religion, culture, and Pancasila as the national ideology (National Education Ministry, 2010, p.8). Indonesian citizens are a religious and multicultural citizen. Every action and the way of life are based on their religion, belief, culture and national ideology. Dewantara (2013, p.72) argues that culture is a mature human soul. There is an inner attitude inside. Thus, the values included consider religion, belief, ideology, and culture as the basis. It is expected that the values can form the attitude of young generation.

The values of character education is expected to be integrated into teaching and learning process. Teachers may integrate it through activities inside the classroom using media. However, the books provided by the government did not facilitate the students to develop their students' characters. They need another media to support the teaching and learning to occur and to support the integration of values. Media are communication tools to transfer message and stimulate thinking, feeling, and competence to promote effective and efficient learning (Arsyad, 2012, pp. 38-39). One of media usually used is a worksheet.

National Education Department (2005, p.4) defines a worksheet as sheets embodying tasks which become one way to improve students' involvement and make the teaching and learning process easier. Through worksheets, the students should be directed to build the concepts through own learning in a group work. Moreover, worksheets can be understood as ready-made learning materials and learned by the students individually (Prastowo, 2012, p.204).

Therefore, to fulfill the gap, developing a character-based worksheet for History class is needed. The development of the worksheet was integrated with values in character education.

\section{Method}

This study belonged to Research and Development, a process used to develop and validate educational product (Borg and Gall, 1983, p. 772). The product can be a set of learning materials, movies for teaching, even a procedure or teaching method. In this study, seven steps from Borg and Gall (1983) were adapted. They included (1) research and information collecting, (2) planning, (3) preliminary form of product development, (4) preliminary field testing, (5) main product revision, (6) main field testing, and (7) operational product revision.

This study was conducted in SMA N 1 Depok, Yogyakarta, Indonesia. This school had been implemented the newest 2013 curriculum. The subject of this research was three classes of grade X students. Each of which consisted of 30 students. The data for this research were collected through various techniques including observation, survey, and interview. The data then were analyzed qualitatively and quantitatively. The focus of this research was on the development of the product, and the evaluation (expert judgments and field testing). The evaluation covered by the experts included the feasibility of the content, presentation, context, layout, and language. Meanwhile, the evaluation form for the students covered the feasibility of the content, language, and attentiveness. The evaluation sheet was using $1-5$ Likert scale. The feasibility of the product was analyzed based on the criteria of product feasibility as presented on Table 1. 
Tabel 1 Product feasibility criteria

\begin{tabular}{ccc}
\hline No & Range & Criteria \\
\hline 1. & $1 \leq \mathrm{x} \leq 1.79$ & Very poor \\
2. & $1.8 \leq \mathrm{x} \leq 2.59$ & Poor \\
3. & $2.6 \leq \mathrm{x} \leq 3.39$ & Fair \\
4. & $3.4 \leq \mathrm{x} \leq 4.19$ & Good \\
5. & $4.2 \leq \mathrm{x} \leq 5$ & Very good \\
\hline
\end{tabular}

\section{Results}

\section{A) Need Analysis Result}

Need analysis was employed to find the students' need in History class. The result was used as the basis for the development. The core competence and basic competence in 2013 curriculum and the textbook used were analyzed. The students' needs were obtained through questionnaires. The values needed to be integrated were obtained from interview with the History teacher.

The result showed that the materials learned were based on 2013 curriculum. The textbook used did not accommodate the students' creativity and participation in the classroom. The integration of character was lack. Based on the interview results, the teacher provided some lists of values need to be integrated. It included religious, honest, disciplined, hardworking, tolerant, curious, nationalist, patriotic, peace, and responsible. In regard to students' learning needs, most of the students prefer illustrations and picture to materials to be presented in the book. They also like working with group and pairs.

In order to fulfill the needs, the development of the worksheet considers the results. It included simple presentation of materials and character values integration. The activities presented required the students' creativity, critical thinking, and active participation. The design of worksheet covered six chapters for a year learning. Each of which consisted of an individual project, pair discussion, group work, case study, presentation, and observation. The activities were arranged based on the values integrated.

\section{B) Expert Judgment Result}

To gain the validity, the worksheets developed were validated by experts in the field, materials, and media. The focus of the evaluation was on the feasibility of the content, presentation, context, layout, and language. Based on the result, the worksheets had met the criteria of feasible. The content showed mean score as 4.3 fitting the criteria "very good" with percentage $87.5 \%$ of feasibility. The score was valid for the feasibility of the context showing the same mean score as which for 4.3 (very good. Moreover, the feasibility of the presentation gained mean score as 4.1 fitting the criteria "good". It can be concluded that from the view of the expert of materials, the worksheet can be stated as feasible. The detailed score can be seen on Table 2. 
Tabel 2 Expert judgment results (materials)

\begin{tabular}{lccc}
\hline Aspects & Total & Percentage & Mean score \\
\hline Content & 70 & $87.5 \%$ & 4.3 \\
Presentation & 37 & $82 \%$ & 4.1 \\
Context & 39 & $86 \%$ & 4.3 \\
\hline
\end{tabular}

From the view of expert in media, the worksheet developed can be said as feasible or appropriate. The feasibility of the layout gained mean score as 4.4 meeting the criteria "very good". The language used had been feasible. The mean score was 4.5 which can be categorized as "very good". It can be seen on Table 3.

Tabel 3 Expert judgment result (media)

\begin{tabular}{lccc}
\hline Aspects & Total & Percentage & Mean score \\
\hline Layout & 128 & $85 \%$ & 4.4 \\
Language & 54 & $90 \%$ & 4.5 \\
\hline
\end{tabular}

From the two experts, the worksheet developed can be said as feasible or appropriate to be used.

\section{C) Field Testing Result}

After the worksheets had been validated, they were field-tested in small scale. The worksheets were evaluated by the students of grade X Social science. Nine students were selected randomly to be the subject. They filled the questionnaires by checking the appropriate scale showing the implementation of the product. The aspects to be covered was the feasibility of the materials, language, and attractiveness.

The feasibility of both materials and language aspect showed mean score as 4.0 meeting the criteria "good". While the aspect of attractiveness showed mean score 4.3 categorized as "very good". It meant that the product developed had been feasible for field-testing in a large scale.

Operational field-testing was employed after the product had been tried out in small scale. All grade X students of Social science were involved. The worksheets tried out were the first three chapters as the schedule and the materials learned on the semester were considered.

The result showed that the content feasibility of each chapter was categorized as "good". The mean score gained each was 3.9, 4.0, and 4.0. The mean score for language feasibility of each chapter showed 4.2. Thus, it met the criteria "good". The last aspect, the attractiveness, gained mean score as 4.0, 4.2, and 4.2. The score above can be classified as "good". The detailed score can be seen on table 4. 
Tabel 4 Operational field testing

\begin{tabular}{|c|c|c|c|c|c|c|c|}
\hline \multirow{2}{*}{\multicolumn{2}{|c|}{ Class }} & \multicolumn{6}{|c|}{ ASPECT } \\
\hline & & \multicolumn{2}{|l|}{ Content } & \multicolumn{2}{|c|}{ Language } & \multicolumn{2}{|c|}{ Attractiveness } \\
\hline CHAPTER I & XIS 2 & $78.2 \%$ & 3.9 & $86 \%$ & 4.3 & $81.3 \%$ & 4.0 \\
\hline $\begin{array}{c}\text { CHAPTER } \\
\text { II }\end{array}$ & XIS 1 & $81 \%$ & 4.0 & $84 \%$ & 4.2 & $85 \%$ & 4.2 \\
\hline $\begin{array}{c}\text { CHAPTER } \\
\text { III }\end{array}$ & XIS 3 & $80.7 \%$ & 4.0 & $83 \%$ & 4.2 & $84 \%$ & 4.2 \\
\hline
\end{tabular}

To conclude, based on the operational field tried out, the product developed can be said as feasible or appropriate to be implemented in the future. Besides, during the operational field testing, the students showed their interest in the lesson. They were very active and engaged in every activity. They discussed the problem they had with their pairs or group.

\section{Discussion}

According to main design of character education (Education Ministry, 2010, p.5), the aims of character education at school include: (1) facilitating reinforcement and development of the values since the students were at school and after they graduate, (2) correcting students' behavior which violates the values integrating at school, (3) building a harmonious relation with family and society as playing the same role. It implies that students' attitude may be formed and reinforced through the school facilitation. It can be done through activities inside and outside the class.

The integration of characters value was employed in two ways, direct and indirect. The integration can be started in the beginning of the lesson through presenting the values in the goal or objectives of the lesson. Besides, the direct integration was accomplished by presenting a corner column defining and explaining briefly about the value.

The second was conducted indirectly or implicitly through the form of activities presented. For example, to encourage the students' curiosity, the activities required them to actively find the answer through reviewing many resources. They also can develop their tolerance through working and having discussion in a group. However, the selection of activities was not merely based on the values to be integrated. The teachers need to consider the objectives of the lesson to help the students achieve the core competence and basic competence mentioned in the 2013 curriculum. Philips (2008, p.73) argues that the teacher needs to consider the relation between the objectives and the activity. The selection of activity should be based on the objective of the lessons. Hunt and Wake (2007, p.21) emphasize that teachers should design new worksheets and browse the internet to find new and fresh resources. By designing own materials, the teacher can achieve the objectives intended.

Besides, the indirect integration can be done through the implicit instruction. For example, to do reinforcement on value "patriotism", the instruction was "Tulislah sebuah esai menggunakan bahasa Indonesia yang baik dan benar sesuai dengan ejaan yang disempurnakan (Write an essay using correct 
and standard form of Indonesian). The students were asked to write an essay using correct and standard grammar and language of Indonesian.

Teaching and learning nowadays focuses only on the low cognitive level like memorizing or transferring knowledge (Suryaman, et.al, 2012, p.19). The students were not required to think higher. Therefore, this worksheet also encompassed a feature namely "Innovative Creative" which involves some activities requiring the students to think critically and be creative. They should be aware of the condition around the environment to help them facing the globalization.

In the end of each chapter, the students were provided by a reflection column. This helped the students to reflect on the materials they have learned. Besides, in order to do reinforcement in the values implemented, the students were asked to fill table to state their attitude toward the issue. The table was not the only way to measure students' improvement on the values integrated. The values cannot be measured only in a short time. The assessment or evaluation needs to be done in a long time by considering another factor surrounding.

\section{Conclusion}

To support the program of character education, developing a worksheet integrating some values is great to be conducted. This research and development had proven that it was actually easy to design such worksheet, particularly for History class. Six chapters were developed based on Core competence and basic competence of the 2013 curriculum. Ten values including religious, honest, discipline, hardworking, tolerant, curious, nationalist, patriotic, peace and responsible. The worksheets had been proven by experts and through field-testing that they were feasible or appropriate to be implemented or used in the future as they met the students' need and the employed curriculum.

The integration of character can be done directly through the objectives of the lesson and a corner column explaining the values briefly. Besides, it can be employed indirectly. The choice of activities and the way of structuring the instruction may help the teachers to integrate some values.

\section{References}

Arsyad, A. (2012). Media Pembelajaran. Jakarta: PT. Raja Grafindo Persada.

Berkowitz, M. W. (2011). Understanding Effective Character Education. CSEE Connections, December 2011-January 2012, the Center for Spiritual and Ethical Education.

Borg, Walter. R \& Gall, Meredith, D. (1983). Educational Research: An Introduction (4 ${ }^{\text {th }}$ Ed). New York: Longman.

Hunt, M., \& Wake, G. (2007). Planning. In M. Hunt (Ed), A Practical Guide to Teaching History in the Secondary School. New York: Routledge.

Dewantara, K.H. (2013). Pemikiran, Konsepsi, Keteladanan, Sikap Merdeka I (Pendidikan). Yogyakarta: UST-PRESS.

Yogyakarta: UST-PRESS.

(2013). Pemikiran, Konsepsi, Keteladanan, Sikap Merdeka II (Kebudayaan).

Lickona, T. (1992). Educating For Character How Our School Can Teach Respect and Responsibility. New York: Bantam books. 
Marlyn, W. (2014). Developmental Discipline and Moral Education. In L.Nucci, D. Narvaez, \& T. Krettenuer (Eds), Handbook of Moral and Character Education. Routledge: New York.

National Education Department. (2008). Peraturan Menteri Pendidikan Nasional RI Nomor 41 Tahun 2008. Panduan Pengembangan Bahan Ajar.

Prastowo, A. (2012). Panduan Kreatif Membuat Bahan Ajar Inovatif .Yogyakarta: IDiva Press.

Phillips, I. (2008). Teaching History: Developing as a Reflective Secondary Teacher. London: Sage Publications.

Republik Indonesia. Kementrian Pendidikan Nasional. (2010). Tentang Pengembangan Nilai Karakter

Rusman. (2011). Model- model Pembelajaran: Mengembangkan Profesionalisme Guru. Jakarta: Rajawali Pers.

Suryaman, et.al. (2012). Pengembangan model panduan pendidik: Pengajaran sastra berbasis pendidikan karakter. Jurnal Kependidikan, 42(1).

\section{Copyrights}

Copyright for this article is retained by the author(s), with first publication rights granted to the journal.

This is an open-access article distributed under the terms and conditions of the Creative Commons Attribution license (http://creativecommons.org/licenses/by/4.0/). 